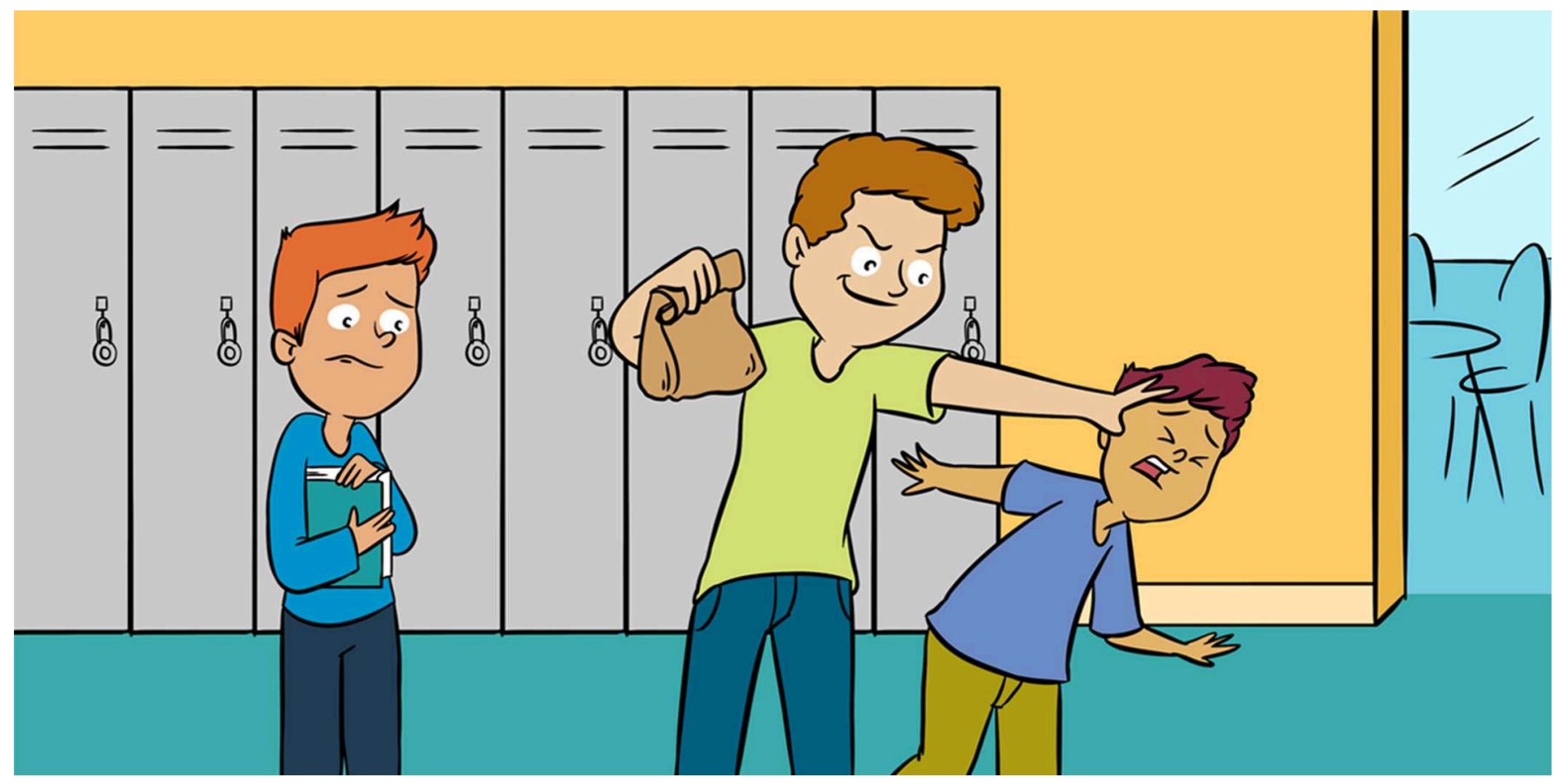

\title{
TELLING SOMEONE AND TELLING ON SOMEONE-IS THERE A DIFFERENCE?
}

\section{Michelle Kennedy*, Larisa McLoughlin and Amanda Clacy}

Sunshine Coast Mind and Neuroscience-Thompson Institute, University of the Sunshine Coast, Sunshine Coast, QLD, Australia

YOUNG REVIEWERS:

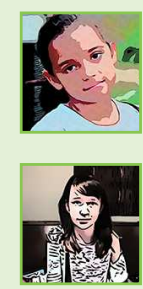

AKSHARA

AGE: 9

SOPHIA

AGE: 12
Have you ever been in a situation where you have asked yourself whether you should tell on a person because he or she is not doing the right thing? An example of this might be that you see someone on the school grounds pulling a branch from a tree and that person then tries to hit other children with the branch when they pass by. In your mind, you might start thinking about what might happen if you speak up. Will you get in trouble? Will the person you told on be angry with you? Will someone get hurt if you do not say anything? When faced with such decisions, it is important to understand the difference between telling on someone and telling someone. When we tell on someone (also called dobbing or snitching), we are trying to get someone in trouble on purpose. Telling someone is different, as we are speaking up because we are worried that something bad might happen or someone might get hurt. Our brains help us make decisions based on our past experiences and current thoughts ... but sometimes parts of the brain can make this process even more confusing. 


\section{DECIDING WHETHER TO TELL SOMEONE CAN BE DIFFICULT}

Imagine you are waiting in line to buy your school lunch and you notice someone running to get in the line before another person. Let us call the running person John. John turns around and says to the person behind him in line, "Ha ha, beat you!" Then you notice John starts to annoy, let us call him Matt, by saying, "You are a loser, too slow to beat me!" John starts to push Matt with his chest, and then Matt falls over. At first glance, John might just be teasing Matt, however when he starts to push Matt and Matt falls over, this becomes a more serious problem, even though Matt stands back up and is okay.

Matt needs to decide whether to speak up or not, but he is having trouble, because this is a complex decision to make. Should Matt tell someone? Whom should he tell? Will John be angry if Matt tells on him? If Matt tells an adult, will the adult listen, or will that adult just get annoyed?

When Matt, or any person, is trying to decide what to do in this type of situation, it is important to understand two things:

1. The difference between telling on someone and telling someone.

2. The role the brain plays when we are making a decision.

\section{WHAT IS TELLING ON SOMEONE?}

Telling on someone can be called various things, such as dobbing, tattling, or snitching. These terms mean the same thing, however, for this article, we will use the phrase telling on someone. Telling on someone is when you try to get a person in trouble on purpose, and the action you are telling on them about generally is not hurting anyone. Let us think about John and Matt in the school lunch line. Matt is thinking about telling the teacher, because he does not like the way John is talking to him, but he is not sure if this is telling on someone or telling someone.

Here are a few questions that might help Matt make a decision in this situation:

a) Does Matt just want to get John in trouble?

b) Can Matt solve this problem himself?

c) Is this problem important or urgent?

d) Is Matt in danger?

If John had only called Matt names and Matt had told on John, this would be considered telling on someone, because Matt was not in danger and Matt could have solved the problem by asking John to 


\section{BRAIN STEM}

The part of the brain that controls the flow of messages between the brain and body and controls body functions, like breathing.

\section{CEREBRUM}

The largest part of the brain, which is divided into two halves responsible for processing information that comes in via the senses.

\section{PRE-FRONTAL} CORTEX

An area of the brain involved in planning, decision making and regulating emotions.

\section{AMYGDALA}

The brain area involved with responding to emotions, such as fear.

\section{HIPPOCAMPUS}

An area of the brain involved in the formation of new memories and switching off the amygdala when there is no threat. stop. However, when John started pushing him, Matt needed to tell someone, because he was in danger of being hurt.

\section{WHAT IS TELLㄴNG SOMEONE?}

Telling someone is when you tell another person, usually an adult, about something serious that you cannot solve yourself, such as a situation in which someone is in danger of being hurt. Matt needs to tell someone what happened in the lunch line, since he could have been seriously hurt. Hopefully, Matt understands that this is a serious problem and that he should tell a teacher to hopefully prevent John from doing this to someone else.

\section{THE BRAIN'S ROLE IN DECISION-MAKING}

Now we know the difference between telling on someone and telling someone. But, making the decision to tell someone can still be a tough one. Sometimes we do not realize the role the brain plays when we are trying to make a complex decision, because different parts of the brain are activated when we are trying to make that decision.

What happens in your brain when you are making a decision?

1. When you observe something, you are activating parts of the brain that help to process information from your senses. The brain areas that help with this are the brain stem and parts of the cerebrum.

2. When you make a decision about what to do with the sensory information you observed, you activate the front part of the brain, which is associated with reasoning and problem solving, known as the pre-frontal cortex.

3. When you are unsure or worried about making a decision, you may be activating parts of the brain associated with emotions, such as fear or anxiety. The amygdala's role is to regulate the fear response. Also, your brain may retrieve an anxious memory from the hippocampus, making it hard to decide what to do (Figure 1).

\section{THE BRAIN'S ROLE IN TELLING SOMEONE}

Now that you have a better understanding of the brain's role in decision-making, let us discuss how this relates to telling someone. Most simple decisions that you make, like opening your lunchbox and eating the lunch food, progress through steps 1 and 2. Step one being you open your lunchbox and step 2 being you make a decision to eat your lunch [1]. However, when you are asked to make a more complex decision, such as Matt deciding whether to tell on John, the decision 


\section{Figure 1}

When making a decision, various parts of the brain are activated, including the brain stem, pre-frontal cortex, hippocampus, and amygdala.

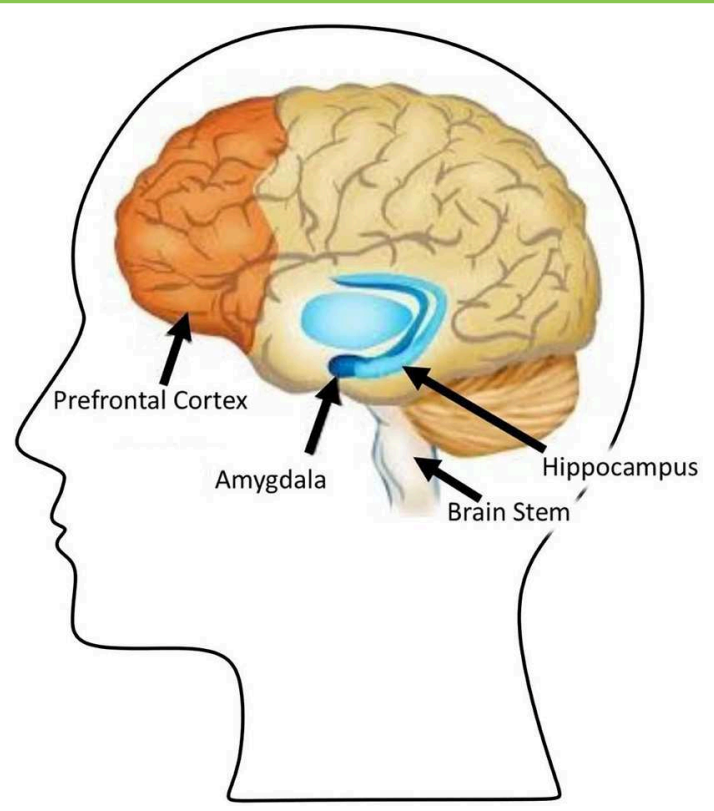

Figure 1

must be broken down into smaller steps [2]. Therefore, step 1, Matt observes what John has said and done. Step 2, Matt tries to decide whether to tell someone or not. Step 3, Matt's decision to tell someone is worrying him, as John might get angry with him.

Therefore, Matt needs to consider the following:

a) Can Matt solve this problem himself? NO

b) Is this problem important or urgent? YES

c) Is Matt in danger? YES

d) Does Matt require an adult to solve this problem? YES

When considering the answers to the above steps, Matt activates his pre-frontal cortex to reason and problem-solve, enabling him to reach an answer to each of the steps. From answering these questions, Matt will probably decide that he needs to tell someone about what happened with John in the lunch line.

Step 3 has caused Matt to feel worried and scared about his decision, because he previously told a teacher about something less important and got into trouble for it. Matt's feelings of worry based on his past experience tell us that his amygdala has been activated as well as his hippocampus, which retrieved the memory of the previous experience. It might be helpful for Matt to realize that perhaps his amygdala has taken over his thoughts and affected his ability to make a decision, due to the stress of his past experience.

When your thoughts are overwhelming and you are not sure which decision to make, research has shown if you breathe slowly and 
deeply this can calm down the overactive parts of the brain [3]. If Matt were to use this breathing strategy and calm his amygdala, which is hijacking the decision-making function of his pre-frontal cortex, he might realize that the situation with John is different from his past experience and that he needs to tell a teacher about John.

\section{FACED WITH A PROBLEM, WHOM SHOULD YOU TELL?}

If you are having trouble deciding whether to tell someone about something you have observed, choosing one of the following options might help you:

- Tell a friend or friends that you can trust about the problem you have seen.

- Tell your parents about the problem you have seen.

- Tell a teacher or other trusted adult about the problem you have seen.

Matt may decide to talk to his friends first about his decision to tell, and if they agree with his decision, they may support him when he tells a teacher. If Matt decides to tell a teacher about what he observed, he needs to choose a teacher he can trust and feel comfortable talking with about the problem. Hopefully he knows a teacher that he believes will do something about the problem. Matt's friends may help him decide which teacher to tell. If Matt cannot choose an adult he can trust at school, he can choose a trusted adult from elsewhere, like a parent or relative, and together they can work out a way to let someone at school know about the problem [4].

\section{WAYS TO TELL SOMEONE ABOUT A PROBLEM}

When telling an adult about the problem he observed, Matt needs to think about the words he uses, so the adult would not think he is telling on someone. Matt could use some of the suggestions below when talking to a teacher.

- "There is something very important I need to tell you ..."

Table 1

The difference between telling someone and telling on someone.

\begin{tabular}{ll}
\hline Telling someone & Telling on someone \\
\hline Getting someone out of trouble & Getting someone in trouble \\
Someone is in danger & Someone is not in danger \\
Problem is important and urgent & Problem is not important \\
An adult is needed to solve the problem & Problem can be solved on your own \\
\hline
\end{tabular}

Table 1 
- "I have seen something and I am not sure if I need to let an adult know ..."

- "I have seen someone repeatedly do something that I know is not right and I do not know what to do ..."

- "May I speak with you privately about something ..."

\section{IMPORTANT THINGS TO REMEMBER}

If you remember the difference between telling on someone and telling someone, you will be able to make the best decision about when to speak up. Speaking up is a brave thing to do. It is important to understand the role your brain plays in decision-making and that certain regions of the brain sometimes hijack your thoughts and make you doubt whether speaking up is the right thing to do. Importantly, remember to breathe deeply when considering your options about telling someone, because this helps to calm the overactive parts of the brain that may be contributing to your difficulty making a decision.

In summary, if you remember the information in Table 1, you will know if speaking up and telling someone is the right decision.

\section{REFERENCES}

1. Silvers, J. A., Insel, C., Powers, A., Franz, P., Helion, C., Martin, R., et al. 2017. The transition from childhood to adolescence is marked by a general decrease in amygdala reactivity and an affect-specific ventral-to-dorsal shift in medial prefrontal recruitment. Dev. Cognit. Neurosci. 25:128-37.

doi: 10.1016/j.den.2016.06.005

2. McGovern Institute for Brain Research (Massachusetts Institute of Technology). How We Make Complex Decisions (Sarafyzad et al., 2019. Science). Retrieved from: http://news.mit.edu/2019/how-brain-complex-decisions-0516

3. Yackle, K., Schwarz, L. A., Kam, K., Sorokin, J. M., Huguenard, J. R., Feldman, J. L., et al. 2017. Breathing control center neurons that promote arousal in mice. Science 355:1411-5. doi: 10.1126/science.aai7984

4. Cortes, K. I., and Kochenderfer-Ladd, B. 2014. To tell or not to tell: what influences children's decisions to report bullying to their teachers? School Psychol. Q. 29:336-48. doi: 10.1037/spq0000078

SUBMITTED: 27 March 2019; ACCEPTED: 22 August 2019; PUBLISHED ONLINE: 18 September 2019.

EDITED BY: Tzipi Horowitz-Kraus, Technion Israel Institute of Technology, Israel

CITATION: Kennedy M, McLoughlin L and Clacy A (2019) Telling Someone and Telling on Someone-Is There a Difference? Front. Young Minds 7:117. doi: 10. 3389/frym.2019.00117 

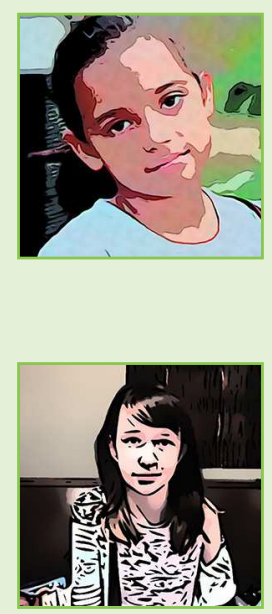

CONFLICT OF INTEREST STATEMENT: The authors declare that the research was conducted in the absence of any commercial or financial relationships that could be construed as a potential conflict of interest.

COPYRIGHT @ 2019 Kennedy, McLoughlin and Clacy. This is an open-access article distributed under the terms of the Creative Commons Attribution License (CC BY). The use, distribution or reproduction in other forums is permitted, provided the original author(s) and the copyright owner(s) are credited and that the original publication in this journal is cited, in accordance with accepted academic practice. No use, distribution or reproduction is permitted which does not comply with these terms.

\section{YOUNG REVIEWERS}

\section{AKSHARA, AGE: 9}

Science is everything, from the art of brushing to the way we interact with nature. All the information we learn is gathered in our brain. Our brain is not just a heavy load on our neck, it actually helps us to have fun, dream, and live. I am eager to know more about the mechanisms of how it functions. My aim is to understand how organisms interact with their environment to create a healthy society.

\section{SOPHIA, AGE: 12}

I am in the sixth grade. I love art and drawing anime. In my class I started a club that meets once a week and I was elected president. I love to travel with my mother, father and two sisters. California is my favorite place, especially Disneyland in Los Angeles and Japan town in San Francisco. My plan is to go to Art College in California and after that to move to Japan. Reviewing articles is fun and I learn a lot.

\section{AUTHORS}

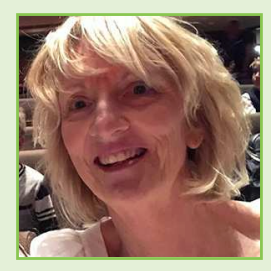

\section{MICHELLE KENNEDY}

I love being out and about enjoying Australia's natural surroundings. Cooking is also something I enjoy doing as I find it a great way to relax. I am a primary school teacher who is passionate about helping primary school aged children understand why they become anxious about their school work, the role the brain plays in their anxiety, and help them develop strategies to deal with their stress. *michelle.kennedy@research.usc.edu.au

\section{LARISA MCLOUGHLIN}

I research cyberbullying and mental health in young people. My research has focused on the importance of social connectedness, and I am looking at how the brain responds to cyberbullying. I really hope to help young people lead healthier and happier lives. Fun fact about me: I am an identical twin. My twin sister is not a Dr. like me but she is an iron woman! I like going to the gym and performing aerial arts when I am not researching. 


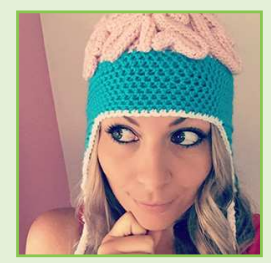

\section{AMANDA CLACY}

In my research on head injuries and mood disorders, I use both neuroscience and community research methods to make sure that I am getting the facts about things that matter most to everyday people. My favorite part of my job is talking to people in the community about what is important to them. My goal as a researcher is to help create a world that brings out the best in people. In my spare time, I like climbing mountains, taking my dogs kayaking, and crocheting brains and fun critters. 